\title{
The Properties of the Manufactured SOFC Unit Cell using Decalcomania Method
}

\author{
Mi-Jai Lee ${ }^{\dagger}$, Bit-Nan Kim, Tae-Young Lim, Sei-Ki Kim, and Byung-Hyun Choi \\ Electronic Materials Laboratory, Korea Institute of Ceramic Engineering and Technology, Seoul 153-801, Korea \\ (Received October 11, 2011; Revised November 11, 2011; Accepted November 14, 2011)
}

\section{전사법을 이용하여 제조한 SOFC 단전지의 특성 분석 \\ 이미재 ${ }^{\dagger} \cdot$ 김빛남 $\cdot$ 임태영 · 김세기 · 최병현 \\ 한국세라믹기술원 전자광소재센터 \\ (2011년 10월 11일 접수 ; 2011년 11월 11일 수정 ; 2011년 11월 14일 채택)}

\begin{abstract}
The properties of manufactured SOFC unit cell using decalcomania method were investigated. The decalcomania method that used in ceramics, dish, vessel and etc. was the very simple process. The SOFC unit cell manufacturer using decalcomania method is very simple process. Especially, the decalcomania method was the most suitable manufacturing method for the segmented type SOFC. The cathode, prevent diffusion layer (PDL), anode functional layer (AFL) and electrolyte were manufactured using decalcomania method on porous anode support. The sintered electrolyte at $1450^{\circ} \mathrm{C}$ for $2 \mathrm{~h}$ using decalcomania method was very dense, and the thickness was about $10 \mu \mathrm{m}$. The cathode, the PDL and the AFL were manufactured using decalcomania method and was sintered at $1250^{\circ} \mathrm{C}$ for $2 \mathrm{~h}$, and the sintered electrodes were the porous. As a result, with humidified hydrogen used as fuel, the cell with an $15 \mu \mathrm{m}$-thick AFL exhibited maximum power densities of $0.246,0.364,0.504 \mathrm{~W} / \mathrm{cm}^{2}$ at $700,750,800^{\circ} \mathrm{C}$, respectively.
\end{abstract}

Key words : Decalcomania method, SOFC, Segmented type, Anode functional layer

\section{1. 서 론}

고체산화물 연료전지(Solid Oxide Fuel Cell)는 전지의 모든 부분이 산화물로 이루어져 있어 내구성과 효율이 높을 뿐만 아니라 고가의 촉매를 사용하지 않아도 되는 장점이 있다. 하지만 연료전지의 특성상 출발물질의 가격이 비쌀 뿐만 아니라 세라믹으로 이루어져 있어 형태 및 크기에 많은 제한이 따르고, 복잡한 형상을 구현하기가 어렵다는 단점이 있다. 이러한 문제점들을 해결하기 위해서 cell의 구조를 변화하여 반응 면적의 극대화를 통해 stack의 크 기를 줄이거나, 새로운 물질을 개발-적용하여 높은 효율을 가지는 $\mathrm{SOFC}$ 의 개발이 활발히 진행 중이다. ${ }^{1-5)}$ 이러한 연구 중 segmented type SOFC는 하나의 지지체에 여러 개의 전지 를 형성하는 방법으로, 이런 구조를 형성하게 될 경우 단전 지 사이의 거리가 짧아 compact한 구조를 가질 뿐만 아니라 전극과 $\mathrm{IC}$ 에서 발생하는 ohmic loss를 최소화하며 단위 부피당 전력 효율이 높고, 기계적 강도가 우수하고 밀봉이 간단하고 열응력 내구성이 높다는 장점을 가지고 있다. ${ }^{6-8)}$

\footnotetext{
${ }^{\dagger}$ Corresponding author : Mi-Jai Lee

E-mail : im1004@kicet.re.kr

Tel : +82-2-3282-2442 Fax : +82-2-3282-7814
}

하지만 screen printing과 같은 방법으로는 지지체 위에 여러 개의 전지를 형성할 때에 굴곡이 있는 지지체의 모서리는 전지를 형성할 수 없기 때문에 추가로 밀봉을 해야 한다는 단점이 있다. 이러한 밀봉의 어려움을 해결하면서 지지체의 굴곡이 있는 모서리에도 전지를 형성함으로써 반응 면적을 극대화하기 위해 전사지를 이용하여 전극을 제조하는 방 법을 사용하였다. 전사지법이란 Fig. 1에 나타냈듯이 주변 에서 흔히 사용하고 있는 그릇이나 컵과 같은 굴곡이 있는 도자기에 무늬를 넣는 방법으로 원하는 모양과 크기로 제 조할 수 있을 뿐만 아니라 제조 공정이 간단하며 굴곡이 있는 면에도 쉽게 적용할 수 있다는 장점을 가지고 있다.

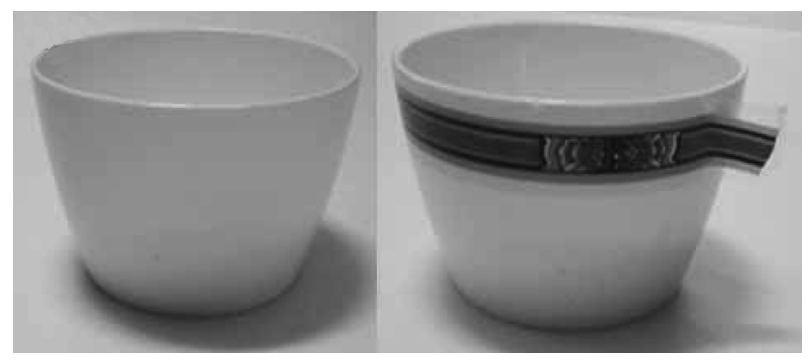

Fig. 1. The decalcomania method. 
따라서 본 연구에서는 연료극 지지체를 제외한 공기극, 확산방지층, 연료극 기능층을 전사법으로 제조하여 연료극 지지체 위에 적용한 $\mathrm{SOFC}$ 단전지를 제조하고, 연료극 기 능층에 따른 전해질의 미세구조 특성을 평가하였다. 또한 최적의 조건에서 제조한 단전지의 계면 및 단면의 미세 구조를 분석하고, 공기극의 분극특성 및 출력을 측정하였다.

\section{2. 실험방법}

전사지 제조를 위한 공정은 Fig. 2에 나타내었는데, 출 발물질로는 연료극과 연료극 기능층은 $\mathrm{YSZ}(8 \mathrm{~mole} \%$ Yttria doped Zirconia)와 $\mathrm{NiO}$ 를, 전해질은 $\mathrm{YSZ}$, 공기극은 $\left(\mathrm{La}_{0.6} \mathrm{Sr}_{0.4}\right)\left(\mathrm{Co}_{0.2} \mathrm{Fe}_{0.8}\right) \mathrm{O}_{3}$, 확산방지층은 $\mathrm{GDC}(10 \mathrm{~mole} \% \mathrm{Gd}$ doped Ceria)를 사용하여 제조하였다. 전사지는 전극 분말과 전사 페이스트를 $1: 0.5$ 의 비율로 하여 고속혼합기를 이용 하여 혼합한 뒤 전사종이 위에 screen print를 이용하여 코 팅한 후 $40^{\circ} \mathrm{C}$ 에서 2 시간 동안 건조 한 뒤 다시 전사 오일을 전면에 코팅하여 $40^{\circ} \mathrm{C}$ 에서 2 시간동안 건조하여 제조하였

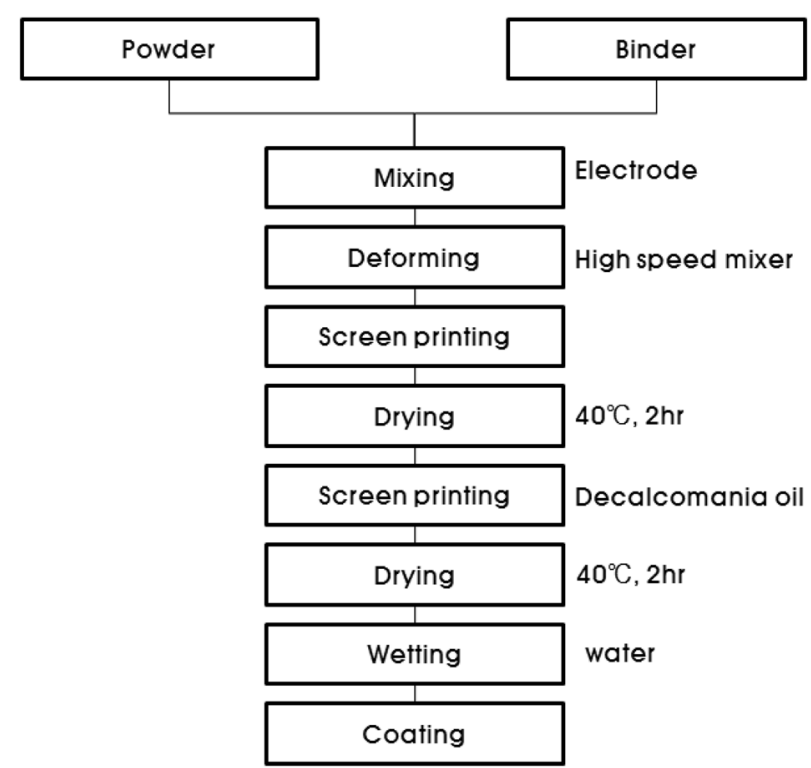

Fig. 2. The manufacture process for the decalcomania method.
다. 이때 사용한 전극 분말은 연료극 기능층의 경우 $\mathrm{NiO}$ : $\mathrm{TZ} 8 \mathrm{Y}$ 의 비율을 $60: 40$ 으로 하였으며, 전사지를 제조할 때에 binder의 함량이 높기 때문에 바인더의 burn out으로 인한 기 공 형성을 고려하여 기공 형성제는 첨가하지 않았다. 전해 질의 경우 Tosho 분말을 사용하였고, 또한 전해질과 공기 극의 반응에 의해 생성되는 2 차상을 막기 위해 입자크기 $0.3 \mu \mathrm{m}$ 의 $\mathrm{GDC}$ 를 확산방지층으로 사용하였으며 공기극은 입자크기 $0.3 \mu \mathrm{m}$ 의 $\mathrm{LSCF}$ 를 사용하였다. 이와 같은 공정으로 제조한 전사지와 전사지를 이용하여 제조한 unit cell을 Fig. 3에 나타내었는데, Fig. 3(a)는 전사지를 cell의 크기에 맞게 원형으로 제작한 사진으로, 제조한 전사지를 이용하여 연료극 지지체에 전극을 제조한 unit cell을 Fig. 3(b)에 나 타내었다. 제조한 unit cell에서 연료극 지지체의 직경은 $20 \mathrm{~mm}$, 두께는 $2.5 \mathrm{~mm}$ 였으며 PDL과 공기극의 경우 직경 $15 \mathrm{~mm}$ 로 반응면적은 $176.6 \mathrm{~mm}^{2}$ 를 가졌다.

연료극 지지체는 $\mathrm{NiO}: \mathrm{TZ} 8 \mathrm{Y}$ 의 비율을 $60: 40$ 으로 하고 기공형성제로 활성탄을 $15 \mathrm{wt} \%$ 첨가하여 ball mill을 이용 하여 24 시간 동안 혼합 한 뒤 $80^{\circ} \mathrm{C}$ 에서 24 시간동안 건조한 분말을 직경 $30 \mathrm{~mm}$, 두께 $3.5 \mathrm{~mm}$ 의 pellet으로 성형하였다. 성형한 연료극 지지체는 $600^{\circ} \mathrm{C}$ 에서 2 시간동안 burn out한 뒤 $1250^{\circ} \mathrm{C}$ 에서 4 시간동안 가소결하였다. 가소결된 연료극 지지체 위에 연료극 기능층 전사지를 코팅 하여 $600^{\circ} \mathrm{C}$ 에서 2 시간동안 burn out한 뒤 $1250^{\circ} \mathrm{C}$ 에서 4 시간동안 가소결하 였다. 전해질의 경우 코팅된 연료극 기능층 위에 전해질 전사지를 2회 코팅한 뒤 $600^{\circ} \mathrm{C}$ 에서 2시간동안 burn out하여 $1450^{\circ} \mathrm{C}$ 에서 4 시간동안 소결하였는데, 이때 dense한 전해질 층을 얻기 위해 $100^{\circ} \mathrm{C} / \mathrm{h}$ 로 천천히 냉각하였다. 공기극과 전 해질 층 사이에는 확산방지층으로써 $\mathrm{GDC}$ 를 사용하였으며 $\mathrm{GDC}$ 는 1회 코팅하고 $\mathrm{LSCF}$ 를 2회 코팅하여 $600^{\circ} \mathrm{C}$ 에서 2시 간동안 burn out한 뒤 $1250^{\circ} \mathrm{C}$ 에서 4 시간동안 소결하여 완성 된 cell을 얻었다. 기공율의 경우 전사지 제조와 동일한 혼합 조성으로 시편을 제조한 후 단전지 제조와 같은 조건에서 열처리 하여, 수은압입법을 이용한 Porosimeter (Micromerics 사, Autopore IV)를 이용하여 측정하였다. 교류 임피던스의 경우 전사지로 제조한 각 전극을 $\mathrm{YSZ}$ 전해질 지지체 위에 형성하여, $800^{\circ} \mathrm{C}$ 에서 Frequency Response Analyzer (Solatron, SI1260)와 Potentiostat/Galvanostat (Solatron, SI1287)을 사

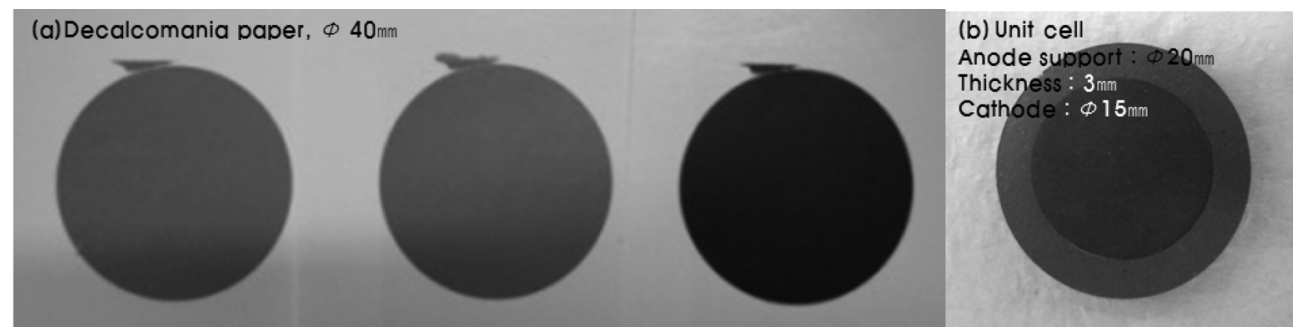

Fig.3. The shape of the manufacturing decalcomania paper and the manufacture unit cell using it. 
용하여 측정하였다. 측정 시 주파수 범위는 $0.1 \mathrm{~Hz} 100 \mathrm{kHz}$ 이고 amplitude는 $10 \mathrm{mV}$ 였다. 이때 $\mathrm{H}_{2}$ gas의 유량은 $200 \mathrm{ml} / \mathrm{min}$ 으로 하였으며 각각 $800^{\circ} \mathrm{C}$ 에서 2 시간동안 환원 시킨 뒤 $800,750,700^{\circ} \mathrm{C}$ 로 온도를 내리면서 측정하였다. 또 한 전사지를 이용하여 제조한 단전지는 $700,750,800^{\circ} \mathrm{C}$ 에서 출력을 측정하였다.

\section{3. 결과 및 고찰}

제조한 전사지의 열처리 조건 확립 및 열처리 시 전지 내부에 존재하는 oil의 잔류 회분량을 확인하기 위해 측 정한 전사 oil의 TG-DSC 측정 결과를 Fig. 4에 나타내었다. 그림의 $\mathrm{TG}$ 를 살펴보면, 약 $400^{\circ} \mathrm{C}$ 에서 전사 oil의 질량이 모두 감소하는 것을 확인할 수 있는데 이는 $400^{\circ} \mathrm{C}$ 에서 전사 oil이 모두 burn out 된다는 것을 알 수 있다. 또한 DSC 그래 프에서 흡열 피크가 나타나고 $543.2^{\circ} \mathrm{C}$ 에서 모든 반응이 끝 나는 것으로 보아 전사 oil에 함유되어 있는 유기용매 및

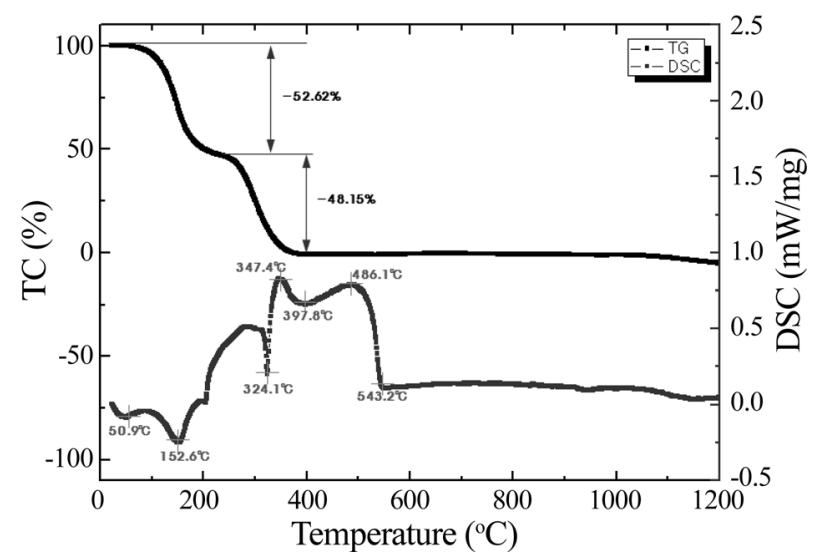

Fig. 4. TG-DSC of decalcomania oil.
바인더가 약 $550^{\circ} \mathrm{C}$ 에서 열에 의해 모두 burn out 된다는 것을 알 수 있었다.

Fig. 5에 다공성인 연료극 지지체 표면 위에 치밀한 전해 질을 형성하기 위해 연료극 기능층을 전사지를 이용하여 0 회부터 3 회까지 처리하였을 때 전해질 표면의 미세구조를 나타내었다. 연료극 기능층 처리 횟수를 증가시킴에 따라 점차 치밀한 전해질 층을 형성할 수 있었는데, 0 회와 1 회 처리한 경우 연료극 지지체의 기공으로 인해 전해질의 표면 에 크랙 또는 기공이 형성되어 있는 것을 확인할 수 있 었다. 이에 반해 연료극 기능층을 2 회 처리한 경우와 3 회 처리한 경우 치밀한 전해질 층을 형성하였는데, 3 회 형성한 경우는 도리어 두꺼운 연료극 기능층으로 인해 전해질 표 면이 고르지 않게 형성되는 경향을 나타내었다.

Fig. 6과 Fig. 7에는 연료극 기능층을 전사지로 2회 처리 하여 제조한 단전지의 미세구조와 계면 사진을 나타내었
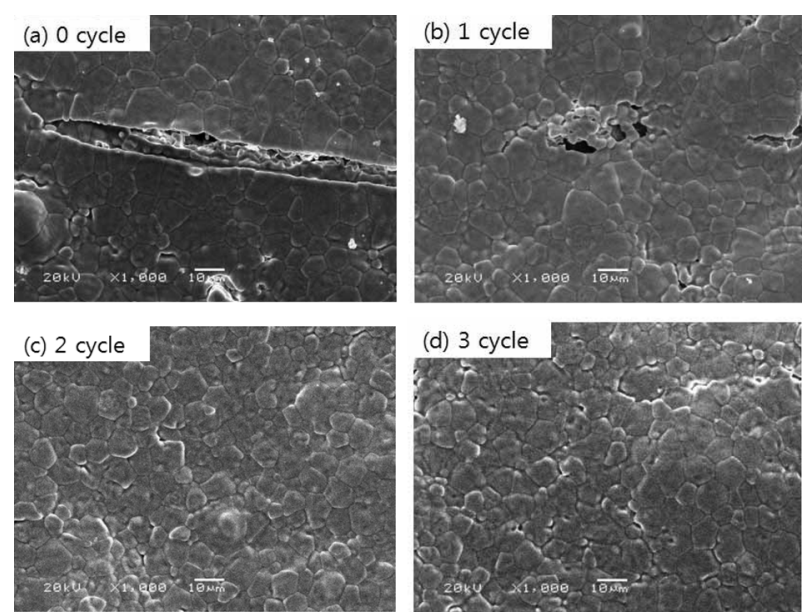

Fig. 5. SEM photographs of the electrolyte according to the number of decalcomania treatment.
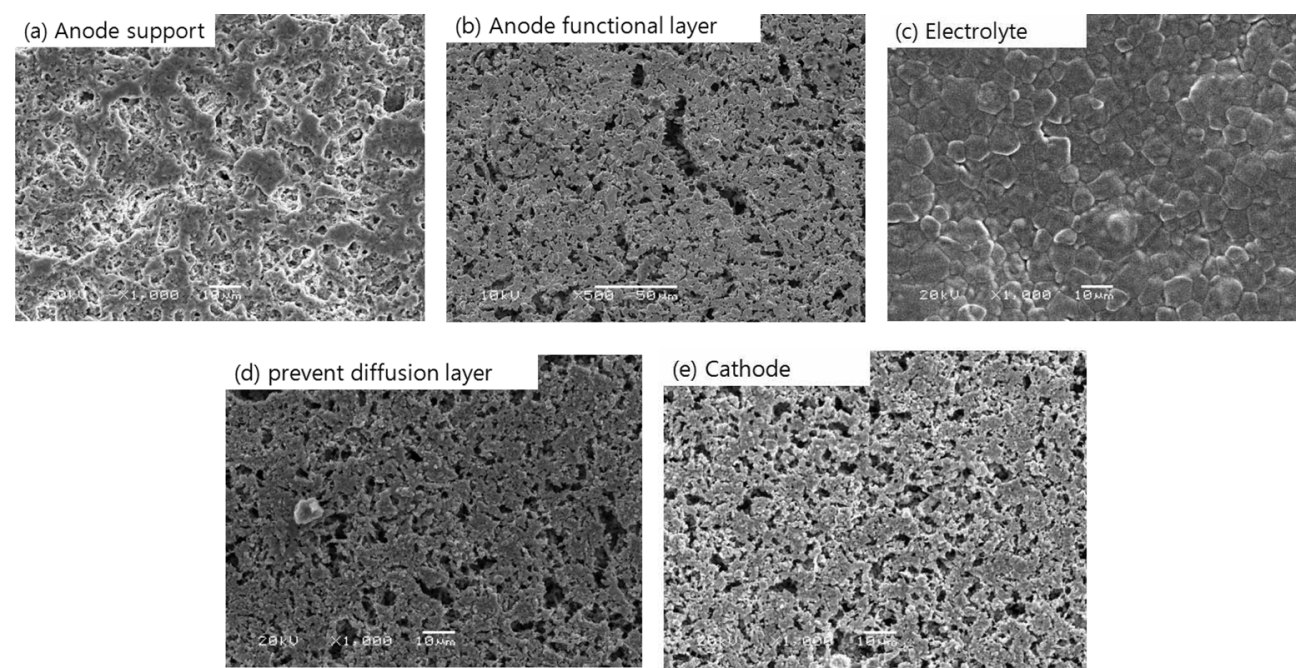

Fig. 6. SEM photographs of the unit cell components. 


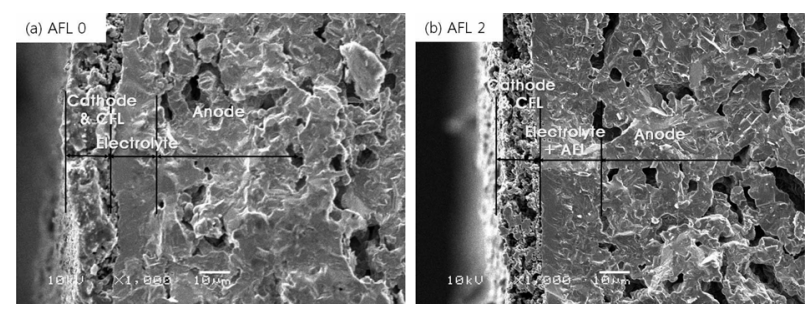

Fig. 7. SEM photographs of the unit cell.

다. Fig.6에서 살펴보면, 연료극 지지체, 연료극 기능층, 공기 극 및 확산방지층 모두 다공성 구조를 나타내고 있으며, 전 해질의 경우는 치밀한 조직을 나타내고 있었다. 각 구성요 소의 기공율을 측정한 결과 연료극 지지체의 경우 약 $32 \%$, 연료극 기능층의 경우는 약 $28 \%$, 확산방지층은 약 $23 \%$, 공 기극은 $39 \%$ 의 기공을 가지고 있었으며, 전해질의 경우는 $0.8 \%$ 정도를 나타내었다.

Fig. 7의 (a)는 연료극 기능층을 적용하지 않은 사진이 고, (b)는 연료극 기능층을 2층 적용한 계면 사진을 나타 낸 것으로 연료극 기능층을 형성하지 않은 (a)의 경우 치 밀한 전해질이 $10 \mu \mathrm{m}$ 두께로 형성되어 있고, 연료극 기능 층을 2 층 적층한 $(\mathrm{b})$ 의 경우 다공성 연료극 지지체 위에 약 $10 \mu \mathrm{m}$ 정도 두께를 갖는 다공성의 연료극 기능층이 형성 되어 있고, 그 위에 치밀한 $10 \mu \mathrm{m}$ 정도의 전해질 층이 형성 되어 있는 것을 확인할 수 있었다. 치밀한 전해질 층 위에 는 약 $15 \mu \mathrm{m}$ 내외의 공기극과 확산방지층이 형성되어 단 전지를 형성하고 있는 것을 볼 수 있었다.

Fig. 8은 전사지를 이용하여 제조한 단전지의 $800^{\circ} \mathrm{C}$ 에서 측정한 교류 임피던스 특성을 cole-cole plot한 결과이다. 일 반적으로 $\mathrm{SOFC}$ 단전지의 경우 cole-cole plot에서 좌측 반원 의 좌측 실수부 시작점을 단전지 스택의 IR (ohmic) 저항 으로, 여기에 좌측 반원의 끝지점 혹은 우측 반원의 시작 지점을 IR 저항과 분극 (polarization) 저항의 합에 의한 저항 으로, 우측 반원의 끝 지점을 IR 저항, 분극저항, 물질 전달 (mass transfer) 저항의 합에 의한 저항으로 분해하여 분석 한다고 보고되어 있다. 본 실험에서 측정한 결과를 살펴보 면 먼저 IR 저항에 있어서 약 $0.1 \Omega$ 이며, 분극저항을 나타내 는 우측 반원의 경우 약 $0.06 \Omega$ 정도를 나타내고 있어 전체 저항의 합은 약 $0.16 \Omega$ 을 나타내었다. 일반적으로 공기극의 산화환원 반응기구를 두 단계 반응으로 나누어 생각해 볼 수 있는데, 산소이온의 확산반응과 산소이온의 표면확산 이다. 이러한 반응은 전극/전해질/기상이 만나는 삼상계면의 양에 따라 달라지는데, 산화환원반응의 활성점인 삼상계면 의 양이 많으면 전극의 분극저항이 감소하고, 삼상계면의 양 이 적으면 분극저항이 증가한다고 알려져 있다. ${ }^{9)}$ 또한, 보통 IR 저항은 gas 농도에 따라 변하지 않으나, mass transport 와 kinetics와 관계된 impedance 부분은 전극의 공극에 따라 변화한다고 보고되고 있으며, 고주파수 영역 반원은 가스

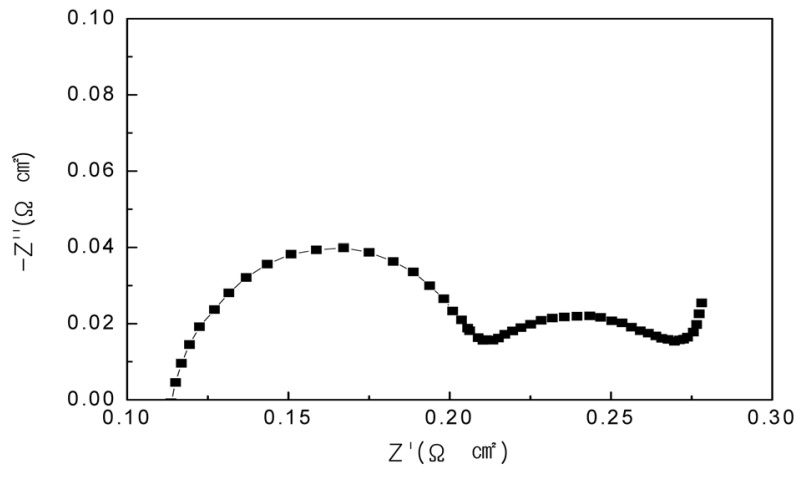

Fig. 8. AC impedance spectra of the unit cell $\left(800^{\circ} \mathrm{C}\right)$.

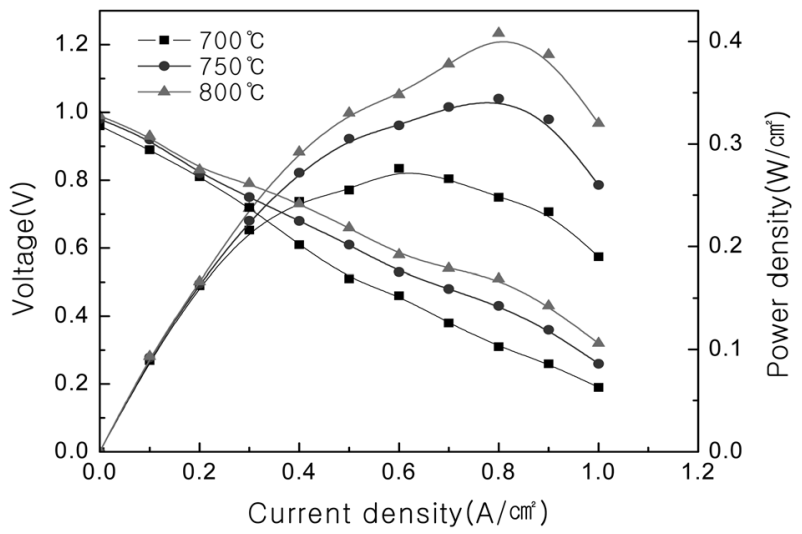

Fig. 9. Performance of the unit cell with hydrogen at different temperature.

분압에 대한 의존성이 거의 없으나 다른 반원은 가스 분압 에 따라 변화한다고 보고되고 있다. ${ }^{10-12)}$ 본 연구에서 전사 법으로 제조한 SOFC 단전지에 있어서 분극저항에 가장 큰 영향을 미치는 것은 기공에 의한 영향으로, 약 $3 \mathrm{~mm}$ 두 께로 제조된 연료극 지지체와 $15 \mu \mathrm{m}$ 내외로 제조된 공기극 의 두께와 기공률 차이에 의해 발생되는 삼상계면의 차이에 의해 발생하는 것으로 생각되어 지는데, 제조한 공기극은 비교적 낮은 기공율 가지고 있으며, 이로 인해 산화환원반 응의 활성점인 삼상계면이 적어져 비교적 높은 저항을 갖는 것으로 보인다. 또한, 측정한 impedance의 경우 오른쪽 반원이 0 에 교차하지 않고 있는 것을 볼 수 있는데, 이는 mass transfer 저항이 큰 것으로 보여지며, 이는 비교적 낮은 기공을 갖는 공기극으로 인한 삼상계면의 감소하고, 이로 인 해 mass transport process가 electrochemical process에 비해 상대적으로 느리게 진행되기 때문이라고 생각되어진다.

Fig. 9에는 연료극 기능층을 2회 처리하였을 때 가장 치 밀한 전해질 구조를 형성한 단전지의 출력특성을 나타내었 다. 출력특성을 살펴보면 $700^{\circ} \mathrm{C}$ 에서 $0.276 \mathrm{~W} / \mathrm{cm}^{2}, 750^{\circ} \mathrm{C}$ 에서 $0.336 \mathrm{~W} / \mathrm{cm}^{2}, 800^{\circ} \mathrm{C}$ 에서 $0.408 \mathrm{~W} / \mathrm{cm}^{2}$ 의 출력을 나타내었다. 따라서, 전사지를 이용한 단전지 제조에 있어 비교적 기공 
의 양이 많은 전극을 형성하여 활성점인 삼상계면의 양이 많아지면 전극의 분극저항이 감소하여 좀 더 양호한 특성을 갖는 전지를 제조할 수 있을 것으로 생각되어 진다.

\section{4. 결 론}

전사법을 이용하여 제조한 단전지의 특성 분석 연구에서 복잡한 형상에 적용이 가능한 방법인 전사법을 이용하여 단전지를 제조하였다. 제조한 단전지는 전해질 층의 경우 연료극 기능층을 전사지로 2 회 처리하여 치밀한 미세조직 을 형성하였으며, 공기극, 확산방지층 및 연료극 기능층을 전사지로 제조하여 다공층을 형성할 수 있었다. 또한 전사 법으로 제조한 연료극 지지체 단전지는 약 $0.16 \Omega$ 의 분극 저항을 나타내었으며, 출력의 경우 $700^{\circ} \mathrm{C}$ 에서 $0.276 \mathrm{~W} / \mathrm{cm}^{2}$, $750^{\circ} \mathrm{C}$ 에서 $0.336 \mathrm{~W} / \mathrm{cm}^{2}, 800^{\circ} \mathrm{C}$ 에서 $0.408 \mathrm{~W} / \mathrm{cm}^{2}$ 을 나타내었 다. 이러한 결과를 통해 복잡한 형상의 스택, 특히 segmented type SOFC에 전사법을 적용하여 스택을 제조할 수 있을 것으로 예상되어 진다.

\section{Acknowledgments}

본 연구는 지식경제부 기술혁신사업인 신재생에너지기 술개발사업-원천기술 (2010T100100622)의 지원으로 수행 되었음을 밝힙니다.

\section{REFERENCES}

1. T. Tsai and S. A Barnett, "Effect of LSM-YSZ Cathode on Thin-Electrolyte Solid Oxide Fuel Cell Performance," Solid State Ionics, 93 207-17 (1997).

2. J. Kong, K. Sun, D. Zhou, N. Zhang, J. Mu, and J. Qiao, "NYSZ Gradient Anode for Anode-supported SOFCs," $J$.
Power. Sources, 166 337-42 (2007).

3. Z. Wang, N. Zhang, J. Qiao, K. Sun, and P. Xu, "Improved SOFC Performance with Continuously Graded Anode Functional Layer," Electrochemistry Communications, 11 1120-23 (2009).

4. K. Chen, X. Chen, Z. Lu, N. Ai, X. Huang, and W. Su, "Performance of an Anode-supported SOFC with Anode Functional Layers," Electrochimcal Acta, 53 7825-830 (2008).

5. N. Ai, Z. Lu, J. Tang, K. Chen, X. Huang, and W. Su, "Improvement of Output Performance of Solid Oxide Fuel Cell by Optimizing Ni/samaria-doped Ceria Anode Functional Layer," J. Power, Sources, 185 153-58 (2008).

6. Y. Bai, J. Liu, and C. Wang, "Performance of Cone-shaped Tubular Anode-supported Segmented-in-series Solid Oxide Fuel Cell Stack Fabricated by Dip Coating Technique," Int. J. Hydro. Energy, 34 7311-15 (2009).

7. T. Lai and S. Barnett, "Effect of Cathode Sheet Resistance on Segmented-in-series SOFC Power Density," J. Power Sources, 164 742-45 (2007).

8. J. Ding and J. Liu, "A Novel Design and Performance of Coneshaped Tubular Anode-supported Segmented-in Series Solid Oxide Fuel Cell Stack," J. Power Sources, $193769-73$ (2009).

9. N. U. Cho, S. C. Hwang, and I. S. Lee, "Single Cell Stacked Planar Type SOFC Assembled using a Ag-current Collector," J. Kor. Ceram. Soc., 44 [12] 720-26 (2007).

10. P. V. Hendriksen, S. Koch, M. Mogensen, Y. L. Liu, and P. H. Larsen, in Solid Oxide Fuel Cells VIII, eds S. C. Singhal and M. Dokiya, The Electrochemical Society Proceedings, Pennington, NJ, PV 2003-07 1147 (2003).

11. J. D. Kim, G. D. Kim, and K. T. Lee, "Oxygen Reduction Mechanism and Electrode Properties of (La,Sr) $\mathrm{MnO}_{3}-\mathrm{YSZ}$ Composite Cathode for Solid Oxide Fuel Cell (Part: Oxygen Reduction Mechanism)," J. Kor. Ceram. Soc., 38 [1] 84-92 (2001).

12. J. D. Kim, G. D. Kim, and K. T. Lee, "Oxygen Reduction Mechanism and Electrode Properties of (La,Sr) $\mathrm{MnO}_{3}-\mathrm{YSZ}$ Composite Cathode for Solid Oxide Fuel Cell (Part : Oxygen Reduction Mechanism)," J. Kor. Ceram. Soc., 38 [1] 93-9 (2001). 